\title{
ЗАСОБИ ЕФЕКТИВНОГО РОЗВИТКУ КОМУНІКАТИВНИХ НАВИЧОК НА ЗАНЯТТЯХ 3 ІНОЗЕМНОЇ МОВИ
}

\begin{abstract}
Анотація. В статті досліджено різні навчальні техніки на заняттях з іноземної мови, що сприяють ефективному розвитку комунікативної компетенції студентів. На думку автора, серед сучасних засобів активізації та опанування навичок комунікації англійською найбільш доречною е сукупність стратегій, що розроблені представниками лексичного підходу у поєднанні з регулярним використанням відеоматеріалів і залученням лінгвістичних ігор. У статті детально розглянуті особливості лексичного підходу, способи його реалізації на заняттях та комунікативні аспекти, що розвиваються в результаті. Також автор аналізуе структурні елементи та засоби організації заняття з залученням лінгвістичних ігор й виділяе їх перспективу для удосконалення різних аспектів комунікації. Детально вивчається спещифіка занять, що базуються на відеоматеріалах, аналізуеться їх структура та особливості опрацювання навчальних задач. Ключові слова: комунікація, інтерактивне заняття, лексичний підхід, відеоматеріали, комунікативні компетенції.
\end{abstract}

Pavlishcheva Yana

Yaroslav Mudryi National Law University

\section{THE MEANS OF COMMUNICATIVE SKILLS DEVELOPMENT AT FOREIGN LANGUAGE CLASSES}

Summary. The article is dedicated to the issue of the effective means of communicative skills development. The author has pointed out three main teaching techniques among them, such as lexical approach, using of videomaterials and linguistic games at English classes. In the introduction the features and peculiarities of communcative methodology in the whole have been described. It is claimed that the main goal of modern ELT is to teach how to apply students' knowledge in practice and real life properly. First of all, it means to be relevant interloquetor, i.e. to fully understand other people during the communication, and express your thoughts so that to be understood by the other communcation participants. The author has emphasized that lexical approach is extremelly valuable tool at English classes due to the development of lexical and grammar language basis necessary for effective communication. As this approach is based on learning lexical chanks and fixed collocations commonly used in daily speaking and different types of speaking as well, its learning techniques are considered to be effective means to develop students' communcative competences. Another powerful tool to strengthen communcative skills is using the videomaterials at English classes. That is because original videos are an inexhaustible source of live authentic language as it is in variety of discourses. They can be creatively used at the lesson in many ways - in terms of vocabulary enlargement, highlighting particular grammar rules in the character's speeches, or to discuss certain topic in the whole. The author has analyzed in detail the structure and organisation of such type of a lesson and kinds of relevant exercises. The importance and effectiveness of applying linguistic games have also been studied. The author has claimed that linguistic game is capable of developing spontaneous speech and helps students to get rid of language barrier. The structure, types of exercises and effect of games on the development of different communicative aspects have also been investigated.

Keywords: communication, interactive lesson, lexical approach, videomaterials, communicatice competences.

$\Pi^{\circ}$ остановка проблеми. Розвиток навичок спілкування та взаеморозуміння сторін в процесі комунікації стало пріоритетною метою серед сучасних методистів та викладачів англійської мови, а комунікативний підхід у викладанні іноземних мов став головною методологічною базою. Опанування іноземною мовою означає в першу чергу оволодіння ㄲï фрункціональним та інтерактивним аспектами, тобто вміння практично застосувати знання мови, вступити в релевантну комунікативну взаємодію з іншою людиною, виразити свою думку зрозуміло й чітко та зрозуміти мову інших мовців. Тому на заняттях 3 іноземної мови стало актуальним питання оволодіння мовними компетенціями у тісному зв'язку 3 їх безпосередньою реалізацією в життевих ситуаціях, починаючи від неформальної комунікації до професійного спілкування. Багато викладачів та методистів намагаються урізноманітнити та творчо розвивати комунікативний підхід на своїх заняттях, доповнюючи його нови- ми елементами та навчальними матеріалами, що представляється можливим завдяки інтернет ресурсам. Це допомагае бути у курсі сучасних та актуальних мовних тенденцій, відстежувати та впроваджувати на заняттях останні зміни в англійській мові, доповнювати вокабуляр студентів найновішою лексикою, а завдяки різноманітним аудіо- та відеоматеріалам наочно демонструвати специфіку комунікації (інтонації, наголоси, емоційний окрас того чи іншого типу мовлення тощо) між носіями мови.

Аналіз останніх досліджувань та публікацій. Серед спеціалістів, що досліджують важливість проблеми розвитку комунікативної компетенції на заняттях 3 іноземної мови, можна виділити роботи О. Борзенко, Ф. Бацевич, О. Бурчені, О. Кузнецової, Т. Бесараб. В іноземній методиці викладання іноземних мов базовими досідженнями 3 опанування комунікативними навичками є праці С. Торнбері, М. Льюіса, К. Брендл, К. Морроу тощо. Якщо узагальнити, 
зазначені вчені наголошують пріоритет розвитку саме комунікативного аспекту у сучасній педагогіці іноземної мови, підкреслюючи, що нагальною потребою та вимогою до викладачів англійської є підготовка студентів в якості учасників міжкультурної комунікації, що насамперед передбачає соціокультурну обізнаність мовців, тобто вміння будувати спілкування таким чином, щоби бути максимально зрозумілим та розуміти інших, долаючи мовний та культурний бар'єри.

Виділення невирішених раніше частин загальної проблеми. Актуальним на даний час представляеться виявлення та комбінація найбільш дієвих навчальних технік для оволодіння комунікативними навичками з іноземної мови.

Метою даного дослідження є огляд та аналіз останніх тенденщій у викладанні англійської мови в аспекті розвитку комунікативної компетенції студентів.

Викладення основного матеріалу. Як зазначалося вище, комунікативний підхід став провідною методикою викладання іноземної мови у сучасній педагогіці. Більш того, всі новітні техніки та методики викладання англійської умовно можна об'єднати як такі, що спрямовані на розвиток та удосконалення комунікативного аспекту. На заняттях 3 англійської мови студенти не стільки вчаться як вживати мовні структури та окремі лексичні одиниці колись у майбутньому, скільки урок будуеться таким чином, щоби максимально бути наближеним до реальних життевих комунікацій. Якщо узагальнити, завдання, які пропонуються студентам та учням до опрацювання, базуються на соціальній взаемодії та функціональних активностях. Розвиток навичок комунікації також підтримуеться інтерактивними видами діяльності , які базуються на парній та груповій роботі студентів, де відпрацьовуються види спілкування реальних життевих ситуацій.

Головними характеристиками комунікативного викладання іноземної мови виступають наступні ознаки:

- успіх та реальні результати у розвитку навичок комунікації залежать в першу чергу від ступеню активної участі студента в процесі навчання як у класі, так і поза заняттями. Таким чином, за підрахунками сучасних методистів співвідношення участі студента та викладача у навчальному процесі мають складати 80\% на 20\%, що означає самостійну позицію студента та фрасилітаторську роль викладача, що спрямовуе та корегуе навчальний процес, але не втручаеться в розвиток власних стратегій навчання студентів;

- вправи, що виконуються на заняттях з іноземної мови мають бути спрямовані на інтерактивну взаємодію студентів між собою $з$ відпрацюванням ситуацій спілкування максимально наближених для реального життя, з метою вільного застосування отриманих знань й поза межами класу;

- на заняттях мають бути представлені різноманітні аутентичні аудіо- та відеоматеріали, що відображатимуть різні мовні дискурси та варіативність мовного матеріалу (акценту, типи англійської тощо). Завдяки цьому, з використанням аутентичної та функціональної мови, має реалізовуватися прагматична мета заняття;
- незважаючи на те, що навичка релевантної комунікації (й в кінцевому результаті, міжкультурної комунікації) є першочерговою задачею комунікативних методик, усі інші мовні аспекти (лексика, граматика, аудіювання, письмо) розвиваються у тісному взаємозв'язку, що в результаті має бути підгрунтям для розвитку комунікативної компетенщії студентів.

Основними елементами, сукупність яких є базою, на якій будується едективна комунікація іноземною мовою, виявляються оволодіння та накопичення мовцем словникового запасу, вміння грамотно та зрозуміло будувати речення, висловлювати свою думку, здатність розуміти мову інших учасників комунікації та адекватно реагувати, вступаючи у комунікативну взаємодію. Реалізувати ці задачі, як демонструе практика викладання англійської у закладах вищої освіти, а також на індивідуальних заняттях або у невеликих групах, вдається завдяки інтерактивним лінгвістичним іграм, застосуванням різноманітних відеоматеріалів й відпрацюванням накопичених знань шляхом дрілів, що пропонуються лексичним підходом. Розглянемо кожний 3 аспектів окремо.

Серед методичних шкіл, що представляють комунікативну методику викладання, лексичний підхід вдало поєднуе в собі як накопичення корисного вокабуляру, необхідного для ефективного спілкування, так і його практичне застосування у мовленні. М. Льюіс, засновник та теоретик лексичного підходу, наголошував на пріоритетності розвитку комунікативних навичок студентів, спираючись на принцип "lexis is a basis", коли вивчення мови спирається не стільки на граматику, скільки на лексику i реалізуеться в першу чергу через інтерактивне спілкування. Щодо опанування лексики М. Льюіс підкреслює їі комплексний характер - у вокабулярі мають бути не окремі слова, а вирази. Запам'ятовування сталих виразів та вміння виділяти у мові лексико-граматичні конструкції ефрективно розвиває швидкість мовлення і також його природність. М. Льюіс називає такі конструкції лексичними чанками (lexical chunks) та сталими словосполученнями (collocations). Як зазначае британський мовознавець Н. Шмітт, лексичні чанки представляють собою фунщіональний аспект мови, найвиразніший спосіб спілкування. Однак не слід вважати, що надаючи перевагу опрацюванню лексики, у лексичному підході зневажається вивчення граматики. Принцип "lexis is a basis" реалізуеться у запам'ятовуванні лексичних чанків, що містять не тільки лексичні одиниці, а й граматичні структури. Більш того, цей метод показує контекст вживання певних граматичних структур та релевантність їх вживання у конкретних ситуаціях, що виявляє важливий аспект розвитку комунікащії - фрункціональність мови.

Одним 3 найефективніших засобів набуття навичок спілкування - це, звичайно, перебування у мовному середовищі носіїв мови, однак не завжди й не в усіх студентів є така можливість. Проте багатим джерелом аутентичного мовного середовища $є$ наявність великої кількості різномантіних відеоматеріалів, що стали широко доступними завдяки інтернет ресурсам. Багато сайтів, серед яких Netflix, що пропонує теледріль- 
ми та серіали різних жанрів, інорормаційні канали, такі як BBC, CNN, подкасти та навчальні платформи для вивчення іноземної мови, такі як english-films.org тощо спроможні дати студентам мовне оточення 3 великим різноманіттям дискурсів і 3 різним рівнем складності, побачити та почути як теоретичний навчальний матеріал втілюеться на практиці, а також самостійно відтворити комунікативну поведінку носіїв мови. Оригінальні відеоматеріали є невичерпним джерелом живої, сучасної мови, яка постійно змінюється та оновлюеться, що є дуже корисним з точки зору відстежування мовних тенденцій та їх залучення на заняттях 3 метою розвитку релевантних комунікативних компетенцій студентів.

Більш того, 3 контенту кожного окремого відеосюжету можна вилучати і демонструвати різні мовні аспекти під різними кутами - на предмет використання певних лексичних одиниць, щоби показати вживання граматичного контексту або з метою ознайомлення та обговорення певної тематики. Слід зауважити, що при роботі з відеоматеріалами студентам відводиться активна роль, що означає підготовлену викладачем й структурно організовану дискусію під час та після перегляду у групі та у парах, виконання відповідних вправ на опрацювання переглянутого сюжету. Таким чином розвиваються навички уважно дивитися, слухати та спостерігати за мовою тіла персонажів, розрізняти навчальний відеосюжет за різними аспектами. Залежно від мети заняття це може бути акцент на розумінні загальної ідеї або окремих лексико-граматичних одиниць.

Щодо організації такого типу комунікативних занять треба враховувати фрактори, що зумовлюють структуру заняття. Серед них - тривалість відеосюжету, його тема та мета, види вправ, що його мають супроводжувати. Як доводить практика занять з використанням відео, оптимальна тривалість відеосюжету не повинна перевищувати п'яти-десяти хвилин в межах заняття тривалістю година або півтори - цього часу вистачить, щоби студент зміг втримати концентрацію на відео і звернути увагу на тематичний матеріал, що опрацьовується. Якщо ж перегляд фрільму або кліпу заповнюють собою весь час заняття, тобто студенти знаходяться в пасивній ролі лише глядачів без можливості спілкування та аналітичного опрацювання відеоматерілу, ефективність такого заняття значно зменшуеться.

Тематично обраний матеріал має корелювати з рівнем знання мови, бути цікавим для даної цільової групи студентів, й, безперечно, реалізувати певну навчальну мету. За таких умов перегляд різноманітних відеосюжетів може виявитися потужним мотиватором для подальшого вивчення іноземної мови. Як стверджують у своєму дослідженні Л.А. Петренко та М.Н. Філіппов, автентичне відео візуально та аудиально стимулює когнітивний інтерес та бажання вивчати іноземну мову, оскільки у той момент, коли студент починає сприймати та розуміти іншомовне середовище, він або вона усвідомлюють, що вивчення мови не було марним і може бути реалізованим на практиці.

Необхідною умовою результативного заняття з використанням відео $є$ не тільки ретельно відібраний відеоматеріал, а й включення різно- манітних інтерактивних вправ, спрямованих на розвиток мовних компетенцій. Структурно такі вправи мають бути включені на різних етапах заняття, а саме: 1) завдання на розігрів перед переглядом кліпу (як правило, це невелика групова дискусія або у парах щодо майбутньої теми відеосюжету); 2) безпосередньо перегляд кліпу й порівняння ідей та припущень висловлених на попередньому етапі; 3) вправи на закріплення вивченого матеріалу після повторної демонстрації відеосюжету, спрямованих на перевірку того, як студенти засвоїли переглянутий матеріал і ще раз закцентувати увагу на тих аспектах, опрацювання яких стояли на меті заняття. При цьому вправи, що використовуються на різних етапах, можуть варіювати, залежно від того, розвиток якої компетенції (або їх комбінації) $є$ пріоритетним на занятті. Так, якщо ціллю є опрацювання нового лексичного матеріалу, перед переглядом відео доречними є створити список найбільш вживаних слів за темою та розробити завдання на їх відповідність певному значенню, а потім продемонструвати їх вживання у контексті шляхом заповнення пропусків у відповідних реченнях. Відповідно, для презентації граматичного матеріалу слід запропонувати вправи, що сфокусують увагу на граматичних аспектах, які будуть акцентуватися у відеокліпі, наприклад, заповнення пропусків у реченнях 3 відповідними граматичними елементами або застосування граматичних ігор.

Перед переглядом відео слід звернути увагу студентів, що перед ними стоятимуть одночасно декілька завдань, які потрібно робити одночасно, оскільки їм доведеться концентруватися на перегляді відосюжету і в той же час виконувати необхідні вправи. Залежно від рівня підготовки учня відео може транслюватися декілька раз або з паузами у найбільш складних фррагментах. Також важливо наголосити, що під час перегляду відео необхідно робити нотатки й помічати ключові слова або фррази, що відповідають заявленій темі, а також на більш просунутих рівнях фріксувати увагу на сталих словосполученнях, ідіомах та часто вживаних граматичних конструкціях, притаманних носіям мови.

Завершальний етап представляе собою огляд та систематизацію матеріалу, що презентується у вступній частині заняття, а також перевірку того, наскільки заявлена тема була засвоєна студентами. Ця частина заняття $є$ найбільш насиченою в аспекті комунікативної взаємодії студентів. Вони працюють у групах або у парах, де шляхом дискусії або за допомогою дрілових вправ намагаються відтворити вивчені лексикограматичні одиниці в процесі спілкування.

Як зазначалося вище, інтернет ресурси є багатим джерелом пошуку відеоматеріалів для використаннях на заняттях з іноземної мови. Більш того, за умов великої кількості таких матеріалів викладач може постійно оновлювати та удосконалювати навчальну програму, підтримуючи актуальність тем занять та мовного матеріалу в цілому. Також слід ураховувати в якості допоміжних ряд оригінальних навчальних платформ, що пропонують корисні відеоресурси для викладачів, де надаються вже готові уроки 3 детально розробленим планом заняття та відповідними 
вправами. Серед таких джерел можна виділити сайти britishcouncil.org, BBClearningenglish, fluentize.com, busyteacher.org та інші. Крім того, викладач має змогу самостійно організовувати такий вид занять, скориставшись YouTube, сайтами новин, епізодами телевізійних шоу або вирізавши фрагменти з фільмів чи телесеріалів.

На заняттях з використанням відеоматеріалів розвиваеться цілий ряд психолінгвістичних аспектів, що сприяють оволодінню навичками вільного спілкування іноземною мовою. По-перше, це аудиовізуальний аспект, тобто в процесі регулярного перегляду відеоматеріалів англійською мовою (особливо без субтитрів) студенти навчаються сприймати та засвоювати спонтанну живу мову безпосередньо, спостерігати за мімікою, жестами, інтонаціями та емоційним станом носіїв мови, намагаються відтворити аутентичну вимову та робити характерні акценти у мовленні. Крім того, фрормуеться специфічне відчуття мови або мовна інтуїція, яка підказуватиме доречність того чи іншого лінгвістичного патерну у мовленні та використання типових сталих словосполучень відповідно до певної соціолінгвістичної ситуації. Таким чином, студент розвиває навичку розуміти мовну одиницю в контексті їі вживання, не звертаючись без зайвої необхідності до словників, а найголовніше, безпосередньо навчається застосовувати дану одиницю у власній практищі спілкування.

По-друге, комунікативна компонента значно покращуеться у тих студентів, що регулярно переглядають аутентичні відеосюжети завдяки постійному збагаченню їх вокабуляра живою розмовною мовою, засвоєнню рекурентних словосполучень та сталих лексичних одиниць (чанків). I тут на допомогу може прийти робота із субтитрами під час перегляду. Корисною практикою може виявится занотовування зазначених лексичних одиниць студентами та розмовна практика дрілів з цими одиницями. Більш того, регулярний перегляд відео англійською аналогічно до перебування у мовному середовищі розвиває незалежність студентів як мовців (оскільки вони змушені менше вдаватися до словникових значень, а більше покладатися на розуміння контексту висловлювання в цілому), додає відчуття впевненості та природності їх власного мовлення.

По-трете, окрім збагачення словникового запасу, відеоматеріали на занняттях англійською $\epsilon$ відмінним наочним засобом вживання граматичних конструкцій. Вивчаючи іноземну мову лише за академічними програмами, студенти не мають змоги побачити практичне застосування граматичних правил, що вивчаються. Тому дуже часто у них відсутне чітке розуміння цих правил й ситуащій, в яких їх треба вживати, тобто студенти часто сприймають граматичний компонент лише теоретично й гірше його запам'ятовують. I підбірка відповідних відеосюжетів може наочно продемонструвати їм як те чи інше граматичне правило працюе в реальності, в конкретних ситуаціях.

I, нарешті, велике різноманіття відеоматеріалів, доступних як онлайн, так і офлайн, слугуе реалізащії індивідуального підходу у викладанні і може бути використане для різних видів підготовки. Так, заняття з використанням відео є едективними для розвитку комунікативних навичок у класах як загальномовної спрямованості, так і у вузькоспещіалізованих напрямках, таких як ділова англійська, за професійним спрямуванням (юридична, медична, технічна тощо). Треба також зазначити, що використовувати відео можна для будь-якого рівня студентів, звичайно, з урахуванням ступеню складності навчальних матеріалів. Так, навіть для початківців перегляд відеоматеріалів може служити відмінною практикою першого знайомства 3 іноземною мовою, її вимовою, граматичними структурами, базовою лексикою, i, найголовніше, слугуватиме стимулом подолати мовний бар'єр та страх розмовляти новою мовою. Студенти середнього та більш просунутих рівнів завдяки регулярному зануренню до автентичного лінгвістичного середовища мають змогу підтримувати та розвивати свої знання.

Наряду 3 використанням відеоматеріалів на заняттях 3 іноземної мови важливим елементом є фрорма проведення інтерактивного заняття 3 акцентом на розвиток комунікативних навичок студентів. Останнім часом викладачі все частіше звертаються до різноманітних лінгвістичних ігор 3 метою практикувати спілкування англійською, відтворюючи різні життеві ситуащії. Головною перевагою цієї навчальної стратегї є опрацювання лексико-граматичного матеріалу в конкретному мовному контексті в процесі спонтанного мовлення. Розмовляючи в ігровій формі, студенти мають змогу застосувати теоретичні знання на практиці. Ігри на заняттях 3 іноземної мови здатні пом'якшити мовний бар'єр, який заважає студентам стати повноцінними учасниками комунікації через страх помилитися, вжити невірне слово або через напружене згадування відповідного граматичного правила. Однак не слід вважати, що заняття 3 використанням ігор є хаотичним й неконтрольованим. Завданням викладача постає детальне планування та створення чіткої послідовної структури уроку із залученням різних комунікативних вправ у групі чи у парах.

Таким чином, лінгвістичні ігри можна розглядати як навчальну стратегію 3 певною структурою і послідовністю з метою ефективного засвоєння навчального матеріалу та практичного застосування отриманих знань в процесі групової комунікації. Як зазначають педагоги та методисти (Gozcu E. та Caganaga C., Yaccob N.S. та Yunus M.M., Klimova B., Borzenko O.), головною відмінністю ігор як навчальної діяльності є поєднання розважального та розвиваючого елементів, що здатне створити у класі творчу атмосфреру, необхідну для плідного, цікавого навчання.

Організація навчальної гри з метою розвитку комунікативних компетенцій студентів має бути побудована на декількох принципах, або структурних елементах. По-перше, всі вправи та види інтерактивних ігор мають корелювати з заявленою темою заняття й бути націленими на відпрацювання певного навчального елементу. Це може бути робота 3 функціональною мовою, перевірка вивченого граматичного матеріалу або закріплення нової лексики в процесі спілкування. По-друге, студенти мають чітко розуміти правила та умови гри й усвідомлювати міри за недотримання цих правил. Тому перед початком гри викладач оголошуе всі відповідні деталі. Потрете, різні види лінгвістичних ігор на заняттях 
мають відбуватися у лімітований проміжок часу, а викладач слідкуе та оголошуе часові рамки. I останне - це підрахунок балів та отримання нагород студентами (градація балів також має бути оголошена перед початком гри).

Щодо видів гри, то вони залежатимуть від того, який мовний аспект є метою заняття. Тобто ігри можуть бути нащілені на опрацювання граматики - наприклад, “передбачення долі” (на закріплення майбутніх часів та конструкції be going to); настільні ігри (наприклад, на ступені порівняння прикметників); “знайдіть того, хто колись...” (на опрацювання Present Perfect) тощо. Також використання ігор є едективним засобом засвоєння лексичного матеріалу заняття - наприклад, “табу”, коли студент має пояснити слово, не називаючи його, а група - вгадати; або гра у категорії слів. Більш того, все різноманіття ігор має універсальний характер, тобто їх можна адаптувати в залежності від теми або мовного аспекту, що опрацьовуеться.

Щодо доречності використання лінгвістичних ігор на певному етапі заняття, то це залежатиме від конкретної навчальної групи ті її потреб та має визначатися викладачем. Інколи грою слід розпочинати заняття, щоби організувати групу та включити когнітивний аспект, що задаватиме фон та настрій подальшому ходу уроку. 3 іншого боку, гру або навіть набір різноманітних ігор можна залучати щоби запобігти втому студентів від складної або монотонної роботи на занятті. Також лінгвістичною грою можна завершити урок, підсумовуючи вивчений матеріал та закріплюючи його в інтерактивній діяльності.

В процесі гри викладач відслідковуе ступінь зацікавленості та участі студентів, корегуе ці елементи та гнучко видозмінюе умови гри, тримаючи у резерві полегшений варіант на випадок складності виконання запропонованих вправ студентами. При цьому треба враховувати складність завдання та умов гри, а також здатність конкретних учнів концентруватися на інтелектуальних задачах. Таким чином, час та умови гри можуть варіювати, але завжди бути чітко оговореними попередньо.

Оголошення результатів ігор є також необхідним елементом, що має корелювати з метою та тематикою заняття. Незважаючи на розважальний характер, лінгвістичні ігри в першу чергу мають на меті навчальну фонкцію, розвиток певної мовної компетенції студентів. Тому для відповідної оцінки та усвідомлення свого рівня компетенції студенти мають отримувати фідбек, адекватний їх рівню знань. В результаті студент може отримати зворотний зв'язок не тільки й не стільки шляхом традиційної системи оцінювання, а також помічаючи реакцію інших членів навчальної групи, усвідомлюючи ступінь свого розуміння ігрової ситуації, відповідних мовних елементів під час пояснення та корегування гри викладачем та результативність власної комунікації з іншими студентами.
Залучення ігрових елементів у вивченні іноземних мов повністю корелюе 3 тими орієнтирами, що має на меті комунікативний підхід. Гра сама по собі $є$ інтерактивною діяльністю, розважальна складова якої так чи інакше захоплюе навіть найпасивніших учасників групи. Навчальна гра передбачае спілкування по заданому алгоритму, й вимагає уважності й концентрації для відповідного реагування в процесі взаємодії 3 іншими учасниками. Незважаючи на певні рамки та умови гри, студенти так чи інакше вдаються до спонтанного мовлення й навчаються сприймати живу мову безпосередньо в процесі комунікації. Крім того, мовні ігри, особливо, коли студентам необхідно відігравати ті чи інші ролі, можуть виступати моделями реальних життевих ситуацій, що навчає використовувати автентичні мовні шаблони в конкретному контексті. Використання ігор на заняттях 3 іноземної мови також виступає ефрективним інструментом для відпрацювання фрункціонального мовлення 3 точки зору лексичного підходу, який згадувався вище. Так, в умовах можна закладати певні мовні шаблони, комбінації слів, ідіоми або сталі вирази, які студенти відпрацьовують шляхом постійного повторення в процесі гри. Наприклад, граючи в “табу", для опрацювання конструкції I have never done... before, студенти мають у парних діалогах згадати якомога більше речей зі свого досвіду, не називаючи їх прямо, інші ж учасники пари вгадують, і так по черзі. Таким чином, в процесі цієї гри кожен учасник багаторазово вживає цільовий мовний патерн, запам'ятовуючи його вживання в контексті живої комунікації.

Висновки та пропозиції. Отже, проаналізувавши навчальні техніки, що пропонує лексичний підхід, особливості використання відеоматеріалів та лінгвістичних ігор на заняттях $з$ іноземної мови, можна стверджувати, що всі вище згадані аспекти специфічним чином сприяють розвитку комунікативних навичок студентів та ведуть до реалізації головної мети комунікативного підходу - усунення мовного бар'єру та вільне спілкування англійською. Більш того, всі вони є елементами навчального процесу, або стратегіями, що доповнюють одна одну. Тобто щоби інтерактивне заняття було максимально ефективним, доречно застосовувати в його рамках елементи кожної зі стратегій. Так, на уроці з використанням відео ряд вправ на опрацювання переглянутого сюжету можливо офрормити у вигляді мовної гри, закріплюючи матеріал, що вивчається шляхом дрілових завдань. Загальними рисами зазначених навчальних технік е якомога більша та активніша участь кожного окремого студента в процесі спілкування, практичне застосування отриманих теоретичних знань, навички незалежного мовлення з мінімальним звертанням до словників чи керівництва викладача, адже саме таким чином формуеться самостійний та впевнений учасник комунікативного процесу.

\section{Список літератури:}

1. Азимова С. Коммуникативный подход в обучении английскому языку. Бюллетень науки и практики. 2019. T. 5. № 4. C. 471-475.

2. Бацевич Ф. Словник термінів міжкультурної комунікації : монографія. Київ : Довіра, 2007. 205 с.

3. Бесараб Т.П. Переваги комунікативного підходу при вивченні іноземних мов у ВНЗ. Наукові записки Національного університету Острозька академія. 2015. № 58. С. 315-317. 
4. Борзенко О. Розвиток комунікативних здібностей та формування іншомовної комунікації при викладанні іноземної мови. Наукові записки. Серія : Філологічні науки. 2017. Випуск 165. С. 453-458.

5. Бурченя О. Роль інтерактивних технологій у навчальному процесі. Нова педагогічна дулка. 2009 . № 2. C. $21-28$.

6. Павліщева Я.О. Лексичний підхід у вивченні англійської мови в юридичних закладах вищої освіти : Матеріали IV Всеукраїнської науково-практичної Інтернет-конференція з міжнародною участю „Іноземні мови у вищій освіті: лінгвістичні, психолого-педагогічні та методичні перспективи”. 2019. URL: http://nauka.nlu.edu.ua (дата звернення: 20.09.2021).

7. Borzenko O., Pavlishcheva Ya. Educational Games with an interactive whiteboard at professional English lessons. Revista Romaneasca pentru Educatie Multidimensionala. 2019. Volume 11, (2). P. 18-37.

8. Brandl K. (2008) Communicative Language Teaching in Action. New Jersey : Pearson Prentice Hall.

9. Kuznetsova O.Yu. Education content issues: theoretical and practical issues. Проблели законності: Національний юридичний університет ілені Ярослава Мудрого. 2017. № 138. С. 230-236.

10. Lewis M. (2002) The Lexical Approach. The State of ELT and a Way Forward. Heinle, $202 \mathrm{p}$.

11. Morrow C.K. (2018) Communicative language testing. The TESOL encyclopedia of English language teaching, 1-7. DOI: https://doi.org/10.1002/9781118784235.eelt0383

12. Thornbury S. (1995) How to teach English. Longman, 157 p.

13. Thornbury S. (2019) Learning language in chunks. Part of the Cambridge Papers in ELT series. Cambridge : Cambridge University Press, $24 \mathrm{p}$.

14. Yaccub N.S., Yunus M.M. Language Games in Teaching and Learning English Grammar: A Literature Review. Arab World English Journal (AWEJ). 2019. Volume 10(1). P. 209-217.

\section{References:}

1. Azimova S. (2019) Kommunicativnij podhod v obuchenii angliiskomu yazyku [Communicative approach in English language teaching]. Bulleten nauki i praktiki, vol. 5, no. 4, pp. 471-475.

2. Bacevich F. (2007) Slovnyk terminiv mizhkulturnoi kommunikacii [Vocabulary of internatioanl communication terms]: monograph. Kyiv: Dovira, 205 p.

3. Besarab T.P. (2015) Perevagy comunicatyvnoho pidhodu pry vyvchenni inozemnyh mov u VNZ [Advantages of the communicative approach in ELL in the higher eduacational establishments]. Scientific notes of National University Ostrozka Academy, no. 58, pp. 315-317.

4. Borzenko O. (2017) Rozvytok komunikatyvnyh zdibnostei ta formuvannya inshomovnoji komunikacii pry vykladanni inozemnoji movy [The development of communicative skills and formation of foreign communication in teaching foreign languages]. Naukovi zapysky. Seriya: Filologichni nauky, issue 165, pp. 453-458.

5. Burchenya O. (2009) Rol interaktyvnyh tehnologij u navchalnomu procesi [The role of interactive technologies in the studying process]. Nova pedagogichna dumka, no. 2, pp. 21-28.

6. Pavlishcheva Ya. (2019) Leksychnyj pidhid u vyvchenni anglijskoji movy v yurydychnyh zakladah vyshchoji osvity [Lexical approach in English language learning in the legal higher institutions]: Materialy IV Vseukrajinskoji naukovo-practychnoji Internet-conferenciji $z$ mizhnarodnoyu uchastyu 'Inozemni movy u vyshchij osviti'. Available at: http://nauka.nlu.edu.ua (accessed 20 September 2021).

7. Borzenko O., Pavlishcheva Ya. (2019) Educational Games with an interactive whiteboard at professional English lessons. Revista Romaneasca pentru Educatie Multidimensionala, vol. 11, (2), pp. 18-37.

8. Brandl K. (2008) Communicative Language Teaching in Action. New Jersey: Pearson Prentice Hall.

9. Kuznetsova O.Yu. (2017) Education content issues: theoretical and practical issues. The issues of legality: Yaroslav Mudryi National Law University, no. 138, pp. 230-236.

10. Lewis M. (2002) The Lexical Approach. The State of ELT and a Way Forward. Heinle, $202 \mathrm{p}$.

11. Morrow C.K. (2018) Communicative language testing. The TESOL encyclopedia of English language teaching, 1-7. DOI: https://doi.org/10.1002/9781118784235.eelt0383

12. Thornbury S. (1995) How to teach English. Longman, 157 p.

13. Thornbury S. (2019) Learning language in chunks. Part of the Cambridge Papers in ELT series. Cambridge: Cambridge University Press, $24 \mathrm{p}$.

14. Yaccub N.S., Yunus M.M. (2019) Language Games in Teaching and Learning English Grammar: A Literature Review. Arab World English Journal (AWEJ), vol. 10(1), pp. 209-217. 